distinguished civil servant to the international community, as scholar and teacher. Before the end of the Second World War, he joined the humanitarian efforts of the United Nations Relief and Rehabilitation Agency, and in 1946 came to the United Nations Legal Department, first as deputy director, then as director. For twenty years he served the world organization to international acclaim for his knowledge and understanding of the law, his contribution to its development, his wisdom, and his dedication to the purposes of the world organization. Later he served with equal distinction as Director of Research and Studies at the United Nations Institute for Training and Research until his appointment to Columbia University where he holds the distinguished chair of Hamilton Fish Professor of International Law and Diplomacy. He has enriched and illuminated the law, as counsel, as teacher, as scholar and author, and has earned the esteem of lawyers and statesmen throughout the world.

\title{
The Francis Deák Prize
}

The Board of Editors of the American Journal of International Law takes pleasure in announcing the award of Deák Prizes for 1981 to Lori Fisler Damrosch for her article, Retaliation or Arbitration-or Both? The 1978 United States-France Aviation Dispute, and Tullio Treves for his Military Installations, Structures, and Devices on the Seabed. The articles appeared in the October 1980 issue, at pages 785 and 808, respectively. The Deák Prize, which was established in memory of the late Francis Deák, is granted for especially meritorious contributions to the Journal by younger authors.

The Board of Editors congratulates Mrs. Damrosch and Professor Treves and once again expresses its appreciation to Mr. Philip Cohen, President of Oceana Publications, Inc.; through whose generosity an award is made to the recipients of the prize.

\section{CORRESPONDENCE}

To THE EDITORS-IN-CHIEF:

January 20, 1981

Günther Handl's interesting article on State Liability for Accidental Transnational Environmental Damage by Private Persons (74 AJIL 525-65) deserves praise for the breadth of the information it offers and the penetrating observations it contains.

I nevertheless regret to say that, however closely I read the article, I cannot overcome the feeling that it suffers from misconceptions. I believe, therefore, that it may be useful to attempt, in a spirit of respectful and constructive criticism, to pinpoint these possible shortcomings.

The author, while observing that state liability for transnational pollution in general falls, as a rule, into the category of liability for fault (page 539, second paragraph), addresses almost exclusively state liability of the type referred to in the title coming within the category of strict liability (or some 
variant of this type of liability that he calls "direct liability," of which more presently). Does this mean that in the author's opinion state liability for accidental transnational damage to the environment by private persons falls solely into the category of strict liability? Does he, in other words, maintain that the only liability of the controlling state that can be engaged for such damage is a strict one? Although the author's position in this regard is not altogether free from ambiguity ( $c f$. the first sentence of page $565)$, the answer appears to be no. For the last paragraph of page 550 , read together with the definition of the "ultrahazardous" activity contained in pages 554-55, appears to confine strict liability coming within the purview of the article's title to liability triggered by ultrahazardous activities, and surely not all private activities capable of resulting in accidental transnational damage to the environment qualify as ultrahazardous. Accordingly, the author should, I feel, either have matched the contents to the title of his article by addressing comprehensively all cases of state liability for the damage to which the title refers, whether or not based on fault, or, more simply, have included in the title, just before "state," the word "strict."

But the matter is perhaps not so simple. For, as has been noted parenthetically, the main theme of the article is not exactly strict state liability for the damage referred to in the title, but, rather, what the author designates as the "direct liability" of states for such damage. (Cf., in particular, on page 564, the first sentence of section VII.) The article, however, hardly gives a clear definition of this term, which, moreover, does not appear to be used consistently throughout. The statement that "direct liability, like strict liability in general, presupposes an element of special danger identifiably connected with the transnationally injurious activity" (page 557) suggests that the term in question designates a species of the genus of strict liability. ( $C f$., further, the reference, on page 551, to "the more limited circumstances that . . . give rise to direct liability.") But, if this is so, the author should have spelled out the distinguishing characteristics of the species. The predominant overall impression is, however, that he uses the term in question as a synonym pure and simple of strict liability. (The impression derives not only from the general tenor of the article, but specifically from footnote 7 , as well as the statement that "direct liability .. . by definition excludes failure by the controlling state to meet its international obligations" [page 554], and the first paragraph of page 565.) But, if this is the case, it would have been preferable for the author to have entirely discarded the former term in favor of the latter.

A number of other questions do not appear to be dealt with as lucidly, logically, or consistently as one would wish. A case in point is that of the last three sentences of the first paragraph of footnote 2. I have trouble with the statement (second of the sentences) that a state can become transnationally liable qua state only if certain conditions are met. Can a state be legally liable otherwise than as (qua) a state? What is meant by the proposition (last of the sentences) that "the crucial test for the incurrence of state liability in the latter sense" (i.e., as territorial sovereign) is "the nature of the activity"? The author should have sought to complement this assertion by indicating what type of activity engages the liability of the state as territorial sovereign and why only activities of this type can have that effect. The application made of the test in question in footnote 97 does not clarify the matter. 
I fail to see the logic behind the first sentence of footnote 30 : surely states $A$ and $B$ can undertake by treaty that $A$ will be liable to $B$ for damages of a certain type inflicted within the territory of $B$ by persons active on the territory of $A$ and vice versa, even though under general international law no liability for such damages attaches to $A$ or $B$.

There appears to be a certain inconsistency in the author's views as to the nature of the general international law standard of state liability. He points out that "the general standard of international liability appears to be clearly based on fault-not in the sense of culpable negligence or malice on the part of the individual state agent but in the sense of a violation of an international obligation incumbent upon the state" (footnote 50, emphasis added). Subsequently, however, the author expresses support for Article 23 of the ILC's draft articles on state responsibility, adding that this article "clearly conveys the idea that a state's international obligation [to prevent a given event from occurring] . . may be considered violated not when the event occurs but when the prohibited event and negligence imputable to the state coincide" (page 540, at footnote 72, emphasis added). I feel not only that the author is reading into the draft article more than it contains, but that he is inconsistent in his views as to the nature of the fault on which the general standard of international liability is based: if, for the purposes of the general standard, this fault is not to be understood "in the sense of a culpable negligence or malice on the part of the . . . state agent," it is difficult to understand why, in the specific case of a duty to prevent the occurrence of a given event, the existence of a breach of that duty requires, in addition to the occurrence of the event, a showing of negligence imputable to the state concerned.

The author affirms that a controlling state's liability for failing to stop continuous transfrontier pollution derives "from its having been negligent or otherwise at fault" for its omission (page 544). However, if he is correct in his view that the controlling state's liability for accidental transnational damage to the environment due to ultrahazardous activities by private parties is strict, then in any case of this type where the damage is continuous, the controlling state's liability for failing to stop it should also be strict.

According to the sentence straddling pages 554 and 555, low probability of accidental transnational damage to the environment resulting from a private activity is a condition that has to be satisfied in order that the activity may qualify as "ultrahazardous." This seems highly paradoxical. One would think that, on the contrary, the higher the probability in question, the stronger is the case for considering that the activity is ultrahazardous.

To conclude, I stress once again that my comments are offered in a spirit of constructive criticism. I would hope that the response the author may wish to make will illuminate the issues he discusses as well as his views thereon (possibly by making it less likely that others will, as I may have, misread his article).

\section{RoBerto Lavalle*}

\footnotetext{
*Although I am a member of the United Nations Secretariat, the views expressed in this letter are purely personal.
} 


\section{Günther Handl replies:}

Roberto Lavalle finds fault with what he calls misconceptions in my article. However, upon close examination most of these turn out to be selfgenerated ones. Over his concern with these "misconceptions" he regrettably neglects those fundamental policy issues addressed in the article which many of us would consider in need of further critical analysis. True, with regard to the question of the article's title he may have a point: Had such an objection been anticipated, the editors would surely have agreed to retain the more precise and longer original title which did refer to "direct state liability." But this is a trivial point, it seems, and one that does not detract from the fact that much of his letter would have benefited from more careful reflection and greater attention to the text of the article.

For example, his query as to whether I consider accidental transnational damage due to private activities always to entail strict state liability strikes one as purely rhetorical in view of the clear exposition-on pages 541, 544 , and 553 - of a state's violation of an international legal obligation as the alternative fault basis of liability. The impression his letter thus conveys is that of a reader who in rushing through a longish and admittedly complex article has missed out on some of the fine print. For how otherwise could he assert that the predominant impression is that "direct liability" is used as a synonym pure and simple for "strict liability"? That the term "direct liability" is used merely as a genus of strict liability should be abundantly clear given the initial delimitation of the topic, the introduction to the differentiation between "private" and "state" activities in footnote 2, the definition offered in footnote 7 , and references throughout the text. The distinction between strict state liability for private activities ("direct liability") and strict state liability in general, which includes liability for state activities in the sense of acta jure imperii (e.g., nuclear weapons tests or hazardous military exercises in border areas resulting in transnational damage) and which is a crucial one, inter alia, with regard to the issue of compensation, is specifically advertised at the outset of the article (footnote 2). That the two notions therefore cannot be coextensive and indeed have not been used to indicate such synonymity should have been obvious. Lavalle's failure to heed this essential distinction may also explain his objection to my reference in footnote 2 to a state's liability qua state. Of course, internationally a state can only be liable in its capacity as the territorial sovereign. To emphasize this in particular would seem to be superfluous. And indeed, the very formulation of footnote 2 readily indicates a totally different purpose of the "qua state" reference, namely, to mark that necessary distinction between "private" and "state" activities. Clearly, my article was limited to a discussion of the former. If the application of the "nature of the activity" test in footnote 97 did not, to Mr. Lavalle's mind, clarify the scope of the latter, he should have found in footnote 124 the listing of examples of such "state" activities whose absence he criticizes.

Mr. Lavalle reaches a key issue when he addresses the general international law standard of state liability, but his misgivings about the "certain inconsistency" he professes to detect in my views are misdirected. His difficulties are as much the result of his failure thoroughly to examine the ILC's draft Article 23 as of his not distinguishing between the fault of a state agent (whose conduct is imputable to the state) and a state's failure 
to meet an international legal obligation that it could have discharged, as the essential prerequisite for a state's incurrence of international liability. Article 23 characterizes, as the ILC's commentary thereto explains, a liability-entailing situation in which the internationally proscribed "event has occurred because the State has failed to prevent it by its own conduct, and ... the State is shown to have been capable of preventing it by different conduct" ([1978] 2 Y.B. Int'l L. Comm'n, pt. 2, at 82-83). In other words, the state's omission is evaluated in accordance with a standard of conduct that, in the light of the circumstances of the situation, the state could reasonably have been expected to adopt. Affirmation by the ILC of the relevance of this contextually determined capacity to act in avoidance of the event thus clearly points to negligence as the additional element on which a finding of a state's international liability will turn. This is particularly well illustrated by the Corfu Channel case. There the Court, upon establishing Albania's obligation to avert harm in view of its knowledge of the existence of the mine field and the approaching British vessels, inquired specifically into whether Albania had also been capable of discharging this obligation. It thereby indicated that Albania's failure to utilize the existing opportunity was the liability-determining element. The decision thus reflects a standard of liability for negligence. Equally clearly, however, it rejects the idea that state liability presupposes culpa on the part of the individual organ of the state.

Mr. Lavalle's final two arguments are, I am afraid, rather convoluted. A common sense approach to the notion "ultrahazardous activity" already suggests conduct that carries an exceptional risk of harm. If risk is properly understood as the product of the probability of an injurious event and the consequences of this event, its exceptional nature in the case of an ultrahazardous activity is not due to a high probability coupled with a low consequence value but the other way round: This, as noted on pages 554-55, should be self-evident from domestic legal provisions bearing on sources of increased danger as well as from such international treaty regimes as on outer space and nuclear power activities. It is thus a hallmark of "ultrahazardous activities" that the realization of the associated exceptional risk is inherently of a low probability: How else would society tolerate hazardous activities such as the operation of, for example, nuclear power plants? Therefore, if the exceptional risk were to materialize on a continuous basis, i.e., the probability of its occurrence would be, mathematically speaking, one, we would find ourselves in a realm where the technical concepts of "abnormally dangerous activity" and "strict liability" would no longer be meaningful. We would obviously face a situation in which a thus qualified activity would be banned outright. This is incidentally why Lavalle's final comment is completely off the mark: There is absolutely nothing paradoxical about viewing the essence of an ultrahazardous activity as posing a risk in the sense of a low probability-high consequence event. The only situation, then, in which continuous injurious transnational effects of an ultrahazardous activity are conceivable, without bringing about the most likely immediate proscription of that very activity, is when the transnational effects are atypical of the hazardous activity. In other words, only where the injurious consequences are within the scope of the abnormal risk that is the basis of liability will strict liability apply. In the case of continuous atypical effects, the liability regime applicable is consequently based on fault. 
Messieurs,

Paris, le 25 février 1981

J'ai lu avec beaucoup d'intérêt l'article du Juge T. O. Elias sur la doctrine du droit intertemporel (The Doctrine of Intertemporal Law) qui a été publié dans votre numéro d'avril 1980. Toutefois, étant moi-même l'auteur d'une thèse de Doctorat sur le même sujet, thèse préparée sous la direction du Professeur Paul Reuter, membre de la Commission du Droit International, soutenue devant la Faculté de Droit de Paris en 1968 et publiée à Paris en 1970 à la Librairie générale de Droit et de Jurisprudence sous le titre Recherches sur l'application dans le temps des actes et des règles en Droit international public (Problemes de droit intertemporel ou de droit transitoire), je me permettrai de présenter quelques observations.

(1) Le Juge Elias consacre des développements (p. 293-96) à trois affaires récentes jugées par des tribunaux nationaux du Royaume-Uni, des Etats-Unis et de la République fédérale d'Allemagne, et notamment à l'affaire Trendtex Trading Corporation $v$. Central Bank of Nigeria. Ces affaires concernent la portée de l'immunité de juridiction des Etats étrangers devant les tribunaux nationaux et montrent que le droit international aurait évolué, puisque l'immunité de l'Etat ne serait plus absolue et qu'il conviendrait de distinguer les actes jure imperii et les actes jure gestionis.

Ces trois affaires posent donc le problème de savoir si le droit international a changé et si les règles coutumières se sont modifiées, mais elles n'apportent rien à la théorie du droit intertemporel. En effet, la question du droit intertemporel ne se pose que si le droit a changé et une. fois que la question du changement du droit a été tranchée. En d'autres termes, le droit intertemporel ne concerne pas le changement du droit en lui-même, ni les résultats ou les méthodes du changement, mais s'intéresse seulement aux conséquences du changement du droit (sur ce point, voir notre thèse, p. 11 et 12). En ce sens on peut dire que le droit intertemporel est la branche du droit qui règle les conflits de lois dans le temps et qu'il s'agit par conséquent d'un jus supra jura. Le Juge Elias aurait d'ailleurs pu se référer à cet égard aux travaux de l'Institut de Droit International qui a examiné cette question de 1968 à 1975 (les rapports du Professeur Max Sørensen et les discussions ont été publiés dans 'Annuaire de l'Institut de Droit International). La résolution adoptée par cet Institut le 12 août 1975 précise en effet "que le problème intertemporel général, dans l'ordre juridique international comme en droit national, concerne la délimitation du domaine d'application des normes dans le temps" (premier considérant).

(2) M. le Juge Elias s'attarde longuement, et avec raison, sur la distinction de Max Huber entre la création et le maintien du droit ("the creation of rights and the existence of rights"). Il souligne que les deux éléments dégagés par Max Huber sont complémentaires, malgré les critiques de certains auteurs (Jessup notamment). Cependant il me semble qu'il faut aller plus loin dans l'analyse. J'ai montré dans ma thèse (p. 266-77) que les deux règles de Max Huber ne sont pas homogènes et qu'elles recèlent une certaine contradiction dans la mesure où Max Huber passe d'un point de vue objectif dans la première règle à un point de vue subjectif dans la seconde.

Il n'en demeure pas moins vrai que le droit intertemporel est dominé par deux impératifs, celui de la sécurité et celui du changement (on re- 
trouve ces deux impératifs en droit européen: voir notre article Le juge communautaire et l'application dans le temps des règlements C.E.E., Annuaire français de Droit international, 1976, p. 169-206). Ces deux exigences avaient été dégagées par le Juge Gros dans l'affaire des Minquiers et des Ecrehous et sont rappelées dans la résolution de l'Institut de Droit International de 1975 . Il en résulte que deux règles dominent le droit intertemporel: la règle de la non rétroactivité et celle de l'effet immédiat (sur cette distinction, voir les observations de $M$. Yasseen, éminent juriste irakien, Annuaire de la Commission du Droit International, 1964, vol. I, p. 43, 730ème sénance).

Les discussions autour du droit intertemporel sont souvent obscurcies parce qu'on ne tient pas compte de l'existence de ces deux règles qui se combinent et se complètent. De même, pour apporter une solution aux problèmes du droit intertemporel il convient de prendre en considération l'objet des règles en conflit (sur ce point, voir notre thèse). C'est ce qui a été omis dans les débats à propos de l'affaire du Sahara Occidental (Western Sahara) que, curieusement, le Juge Elias ne mentionne pas dans son article. Dans cette affaire, le Juge de Castro a consacré une partie de son opinion individuelle à la question du droit intertemporel (C.I.J., Recueil, 1975, p. 168-69) et il met l'accent sur la nécessité d'appliquer les principes de Max Huber. Cependant on peut se demander si le problème du Sahara occidental a été posé correctement: on l'a posé comme étant un problème territorial (et en ce sens on pourrait le rapprocher de l'affaire de l'Ile del Palmas), mais en réalité il soulevait la question de l'autodétermination qui concerne avant tout le peuple, même si elle a des incidences sur le territoire. Le principe d'autodétermination peut donc s'appliquer sans rétroactivité et avec effet immédiat au Sahara occidental.

(3) Le Juge Elias présente également dans son article des considérations intéressantes sur l'affaire du Plateau continental de la Mer Egée et sur le problème de l'interprétation évolutive des traités, problème qui avait été longuement débattu à la Commission du Droit International (voir notre thèse, p. 203-08). Je voudrais simplement ajouter que la résolution adoptée en 1975 par l'Institut de Droit International traite de la question dans son paragraphe 4 et que la Cour Internationale de Justice avait déjà pris position en faveur de l'interprétation évolutive dans l'affaire de la Namibie (C.I.J., Recueil, 1971, p. 31). La Cour européenne des Droits de l'Homme a adopté un point de vue analogue dans les affaires Tyrer (25 avril 1978) et Marckx (13 juin 1979: $\$ 41$ de l'arrêt). Cette dernière affaire est particulièrement intéressante car elle montre les difficultés pratiques soulevées si l'on admet l'interprétation évolutive des conventions. En effet la Cour de Strasbourg a considéré que l'interprétation de la Convention donnée dans son arrêt n'avait pas d'effet rétroactif, c'est-à-dire ne remettait pas en cause des actes ou des situations juridiques antérieurs. Ce faisant, la Cour européenne des Droits de l'Homme s'est inspirée d'un arrêt de la Cour de Justice des Communautés européennes (8 avril 1976, Defrenne/SABENA, Recueil, 1976, p. 481). Cette jurisprudence méritait, je crois, d'être signalée.

En espérant que ces observations seront utiles à vos lecteurs, je vous prie de croire, Messieurs, à mes sentiments très distingués.

Paul Tavernier Université de Paris II 